\title{
Dilignans with a Chromanol Motif Discovered by Molecular Networking from the Stem Barks of Magnolia obovata and Their Proprotein Convertase Subtilisin/Kexin Type 9 Expression Inhibitory Activity
}

\author{
Jongmin Ahn ${ }^{1} \mathbb{D}$, Hee-Sung Chae ${ }^{1}$, Pisey Pel ${ }^{1}$, Young-Mi Kim ${ }^{1}$, Young Hee Choi ${ }^{2} \mathbb{D}^{\text {, Jinwoong }}$ Kim $^{1}$ \\ and Young-Won Chin ${ }^{1, *}$ \\ 1 College of Pharmacy and Research Institute of Pharmaceutical Sciences, Seoul National University, \\ Seoul 08826, Korea; jmahn0205@gmail.com (J.A.); chaeheesung83@gmail.com (H.-S.C.); \\ pisey.1603@gmail.com (P.P.); 0210121@hanmail.net (Y.-M.K.); jwkim@snu.ac.kr (J.K.) \\ 2 College of Pharmacy and Integrated Research Institute for Drug Development, Dongguk University-Seoul, \\ Goyang 10326, Korea; choiyh@dongguk.edu \\ * Correspondence: ywchin@snu.ac.kr; Tel.: +82-2-880-7859
}

Citation: Ahn, J.; Chae, H.-S.; Pel, P.; Kim, Y.-M.; Choi, Y.H.; Kim, J.; Chin, Y.-W. Dilignans with a Chromanol Motif Discovered by Molecular Networking from the Stem Barks of Magnolia obovata and Their Proprotein Convertase Subtilisin/Kexin Type 9 Expression Inhibitory Activity. Biomolecules 2021, 11, 463. https:// doi.org/10.3390/biom11030463

Academic Editor: José

L. Medina-Franco

Received: 28 February 2021

Accepted: 18 March 2021

Published: 19 March 2021

Publisher's Note: MDPI stays neutral with regard to jurisdictional claims in published maps and institutional affiliations.

Copyright: (c) 2021 by the authors. Licensee MDPI, Basel, Switzerland. This article is an open access article distributed under the terms and conditions of the Creative Commons Attribution (CC BY) license (https:// creativecommons.org/licenses/by/ $4.0 /)$.

\begin{abstract}
Natural products have been fundamental materials in drug discovery. Traditional strategies for observing natural products with novel structure and/or biological activity are challenging due to large cost and time consumption. Implementation of the MS/MS-based molecular networking strategy with the in silico annotation tool is expected to expedite the dereplication of secondary metabolites. In this study, using this tool, two new dilignans with a 2-phenyl-3-chromanol motif, obovatolins A (1) and B (2), were discovered from the stem barks of Magnolia obovata Thunb. along with six known compounds (3-8), expanding chemical diversity of lignan skeletons in this natural source. Their structures and configurations were elucidated using spectroscopic data. All isolates were evaluated for their PCSK9 mRNA expression inhibitory activity. Obovatolins A (1) and B (2), and magnolol (3) showed potent lipid controlling activities. To identify transcriptionally controlled genes by 1 along with downregulation of PCSK9, using small set of genes (42 genes) related to lipid metabolism selected from the database, focused bioinformatic analysis was carried out. As a result, it showed the correlations between gene expression under presence of $\mathbf{1}$, which led to detailed insight of the lipid metabolism caused by $\mathbf{1}$.
\end{abstract}

Keywords: Magnolia obovata; Magnoliaceae; dilignans; molecular networking; PCSK9; lipid metabolism genes

\section{Introduction}

Natural products have been considered important sources for drug discovery and development [1]. Conventional strategies (i.e., bioassay-guided isolation) to discover bioactive substances from natural products demand large cost and time consumption (i.e., laborious isolation and identification process of active substances, re-isolation of the same active substances). To overcome one of these drawbacks, various dereplication and structure identification methods have been developed [2]. Among these methods, liquid chromatography tandem mass spectrometry (LC-MS/MS) is the common technology for comprehensive profiling of natural products and helps facilitate structural characterization of constituents in complex mixtures [3-5]. Molecular networking (MN) is one of the recent bioinformatics approaches that estimate structural similarity by comparing MS/MS data $[6,7]$. Recently, this tool has been increasingly used in natural product discovery, which enables to find candidate active molecules directly from fractionated bioactive extracts [8], portray the taxonomic relationship between different plant species [9], or depict 
an overview on chemical diversity between a plant's different parts [3]. Furthermore, computational MS/MS data analysis through in silico annotation tools can improve capturing and inferring structural information from MS/MS data [9-11]. Using these powerful tools superior to traditional dereplication strategies, we could identify analogues with chemical novelty and prioritize secondary metabolites for isolation. The aim of this study was to describe an MS/MS-based molecular networking strategy with the in silico annotation tools that are expected to facilitate the dereplication of secondary metabolites, based on the natural products as fundamental materials in drug discovery.

Excessive levels of low-density lipoprotein cholesterol (LDL-C) can lead to atherosclerotic cardiovascular diseases. Lowering of LDL-C in the plasma has been one strategy for its prevention and treatment [12]. Proprotein convertase subtilisin/kexin type 9 (PCSK9) binds to low-density lipoprotein receptor (LDLR) and forms PCSK9-LDLR complex, which leads to the degradation of LDLR in lysosomes and resultantly increases circulating LDL-C [13]. Thus, inhibition of PCSK9 has been suggested as a new therapeutic target to downregulate LDL-C in the plasma [14]. Recently, various small molecules from natural sources have been reported to modulate PCSK9 expression [15-19]. By PCSK9 mRNA expression monitoring assay in HepG2 cell lines for botanical extracts, the $n$-hexane extracts of the dried stem bark of Magnolia obovata was found to inhibit PCSK9 mRNA expression.

M. obovata Thunb. (Magnoliaceae), a deciduous tree distributed in East Asia, has been traditionally used for the treatment of various disorders (e.g., gastrointestinal disorders, fever, anxiety and allergic diseases) in Northeast Asia [20-22]. Neolignans, particularly honokiol, magnolol, and obovatol, have been reported as the main substances responsible for various biological activities [23,24]. Additionally, diverse lignan derivatives (e.g., sesquiterpene-neolignans and dilignans) derived from major neolignans (magnolol and obovatol) have been discovered in M. obovata [22,24-26]. Herein, to expand the chemical diversity of lignan derivatives in this natural source, an MS/MS-based MN strategy using the Global Natural Products Social Molecular Networking (GNPS) web platform (https: // gnps.ucsd.edu/ProteoSAFe/status.jsp?task=3a3d98903cbc4cc5bbb214fa0c7d1ce4, accessed on 19 March 2021) [27] with in silico annotation via Network Annotation Propagation (NAP) was applied (https: / / proteomics2.ucsd.edu/ProteoSAFe/status.jsp?task=68 0053703c2b49f7ab438882c6badab1, accessed on 19 March 2021)) [28]. In addition, all compounds isolated from the present study were assessed for their PCSK9 expression inhibitory activities. To further understand active compound's effects on lipid metabolism, correlations between lipid metabolism-related gene expression caused by the active compound were assessed and their protein-protein interactions were depicted.

\section{Materials and Methods}

\subsection{General Experimental Procedures}

Optical rotations were obtained with a JASCO P-2000 digital polarimeter (JASCO, Tokyo, Japan). UV and ECD spectra were measured with a Chirascan plus circular dichroism spectrometer (APL, Leatherhead, Surrey, UK). IR spectra were recorded on a JASCO FT/IR-4200 spectrophotometer (JASCO, Tokyo, Japan). $1 \mathrm{D}\left({ }^{1} \mathrm{H}\right.$ and $\left.{ }^{13} \mathrm{C}\right)$ and $2 \mathrm{D}\left({ }^{1} \mathrm{H}_{-}{ }^{1} \mathrm{H}\right.$ COSY, HSQC, and HMBC) NMR spectra were obtained with a Bruker AVANCE-600. The ${ }^{1} \mathrm{H}^{-1} \mathrm{H}$ ROESY NMR spectra were obtained using Bruker AVANCE III HD $850 \mathrm{MHz}$ spectrometer equipped with $5 \mathrm{~mm}$ TCI cryoprobe (Bruker, Billerica, MA, USA). Methanol- $d_{4}$ (Cambridge Isotope Laboratories, Inc., Cambridge, MA, USA) were used as NMR solvents and reference peaks $\left(\delta_{\mathrm{H}} 3.31\right.$ and $\left.\delta_{\mathrm{C}} 49.0\right)$. High resolution-electrospray ionization-mass spectroscopy (HRESIMS) and MS/MS data were obtained using a Waters Xevo G2 Q-TOF mass spectrometer (Waters, Milford, MA, USA). Purifications were performed using MPLC with a Combiflash Companion (Isco, Lincoln, NE, USA) and HPLC with a Gilson 321 pump and Gilson 172 diode array detector (Gilson, Middleton, WI, USA). HPLC columns used for purification were $250 \times 10 \mathrm{~mm}$ Luna $5 \mu \mathrm{m}$ C18 $100 \AA$ (Phenomenex, Seoul, Korea), $250 \times 10 \mathrm{~mm}$ YMC-Pack Ph $5 \mu \mathrm{m} 120 \AA$ (YMC Co., Ltd., Kyoto, Japan), and $250 \times 21 \mathrm{~mm}$ Synergi ${ }^{\text {TM }} 4 \mu \mathrm{m}$ Hydro-RP $80 \AA$ (Phenomenex, Seoul, Korea). HPLC grade solvents were 
purchased from Fisher Scientific Korea Ltd. (Seoul, Korea). Water for HPLC was purified using a Milli-Q system (Millipore, Milford, MA, USA). Solvents for isolation were purchased from Daejung Chemical \& Metal Co., Ltd. (Siheung, Korea).

\subsection{Plant Material}

The dried bark of Magnolia obovata Thunberg (Magnoliaceae) was collected from Mokpo, Jeollanam-do in June 2017, and identified by Dr. H-S. Chae. A voucher specimen (CYWSNU-KP0018) has been deposited at the medicinal plant garden in Seoul National University.

\subsection{MS/MS Molecular Networking}

The sub-fractions of $n$-hexane extract were analyzed with a Waters Acquity UPLC BEH C18 column $\left(150 \mathrm{~mm} \times 2.1 \mathrm{~mm}, 1.7 \mu \mathrm{m}, 40^{\circ} \mathrm{C}\right)$ using the Waters Acquity UHPLCQTOF-MS/MS system (Waters Co., Milford, MA, USA). The mobile phase was water (A) and acetonitrile (B), with the following gradient: 30-95\% B (0-20 min, v/v), 95\% B $(20-23 \mathrm{~min}, v / v)$, and $100 \%(23-27 \mathrm{~min}, v / v)$. The flow rate was $300 \mu \mathrm{L} / \mathrm{min}$, and the injection volume was $2.0 \mu \mathrm{L}$. The MS experiments were performed in data-dependent acquisition (DDA) mode through an electrospray ionization (ESI) condition: negative ion mode, capillary voltage $2.9 \mathrm{kV}$, cone voltage $40 \mathrm{~V}$, source temperature $120^{\circ} \mathrm{C}$, desolvation gas temperature $350{ }^{\circ} \mathrm{C}$, cone gas flow $50 \mathrm{~L} / \mathrm{h}$, and desolvation gas flow $800 \mathrm{~L} / \mathrm{h}$. The full MS survey scan was performed for $150 \mathrm{~ms}$ in the range of 100-1500 Da. The MS/MS data were converted to the .mzXML format using MSConvert and then uploaded on the GNPS web platform (https:/ / gnps.ucsd.edu, accessed on 19 March 2021) for molecular networking. NAP workflow (https: / / proteomics2.ucsd.edu/ProteoSAFe $/$ ?params $=\backslash\{\% 2$ 2workflow\%22:\%22NAP_CCMS2\%22\}, accessed on 19 March 2021) was performed for in silico analysis. All the results and parameters can be accessed with the GNPS job identification for molecular network analysis (https: / / gnps.ucsd.edu/ProteoSAFe/status. jsp?task=3a3d98903cbc4cc5bbb214fa0c7d1ce4, accessed on 19 March 2021) and NAP in silico analysis (https: / / proteomics2.ucsd.edu/ProteoSAFe/status.jsp?task $=680053703 \mathrm{c} 2 \mathrm{~b} 4$ 9f7ab438882c6badab1, accessed on 19 March 2021).

\subsection{Extraction and Isolation}

Dried barks of $M$. obovata $(3.0 \mathrm{~kg})$ were extracted with $94 \%$ ethanol $(10 \mathrm{~L})$ under sonication for $90 \mathrm{~min}$ (three times) at room temperature. After removal of the solvent in vacuo, crude extract $(464.5 \mathrm{~g}$ ) was partitioned with $n$-hexane and water. The $n$-hexane fraction (158.6 g) was subjected to silica gel MPLC using gradient mixtures of $n$-hexane and EtOAc (100:0 $\rightarrow$ 0:100) to yield 11 fractions (H01-H11). H06 (648.3 mg) was separated using RP silica gel MPLC eluted with aq. $\mathrm{CH}_{3} \mathrm{CN}(30 \% \rightarrow 100 \%)$ to 13 subfractions (H06a-H06m). H06i (40.1 mg) was further purified using semipreparative HPLC Luna column $\left(\mathrm{CH}_{3} \mathrm{CN}-\right.$ $\left.\mathrm{H}_{2} \mathrm{O}, 35: 65,2.5 \mathrm{~mL} / \mathrm{min}, 210 \mathrm{~nm}\right)$ to give $\mathbf{1}\left(6.2 \mathrm{mg}\right.$, $\left.\mathrm{t}_{\mathrm{R}} 43.1 \mathrm{~min}\right)$ and $\mathbf{2}\left(4.1 \mathrm{mg}, \mathrm{t}_{\mathrm{R}} 36.2 \mathrm{~min}\right)$ H03 (72.6 g) was fractionated using silica gel MPLC eluted with $n$-hexane-ethylacetate (20:1 $\rightarrow 0: 100$ ) to obtain 4 subfractions (H03a-H03d). Compounds 3 (91.0 mg, $t_{R} 23.9 \mathrm{~min}$ ), $4\left(18.2 \mathrm{mg}, \mathrm{t}_{\mathrm{R}} 22.7 \mathrm{~min}\right)$, and $\mathbf{5}\left(15.1 \mathrm{mg}, \mathrm{t}_{\mathrm{R}} 19.0 \mathrm{~min}\right)$ were purified from a portion of $\mathrm{H} 03 \mathrm{~b}$ by preparative HPLC (Synergi column, $\mathrm{CH}_{3} \mathrm{CN}-\mathrm{H}_{2} \mathrm{O}, 75: 25,5 \mathrm{~mL} / \mathrm{min}, 240 \mathrm{~nm}$ ). H09 $(855.9 \mathrm{mg})$ was fractionated by RP silica MPLC with aq. methanol $(10 \% \rightarrow 100 \%)$ to afford 7 (2.1 mg, H09i), 8 (3.6 mg, H09g), and 13 subfractions (H09a-H09p). H09h (25.6 mg) was further purified by semipreparative HPLC (YMC column, $\mathrm{CH}_{3} \mathrm{CN}-\mathrm{H}_{2} \mathrm{O}, 40: 60,3 \mathrm{~mL} / \mathrm{min}$, $254 \mathrm{~nm}$ ) to give $6\left(6.3 \mathrm{mg}, \mathrm{t}_{\mathrm{R}} 22.4 \mathrm{~min}\right)$.

Obovatolin A (1): pale yellow, amorphous solid; $[\alpha]_{D}^{20}-18.9\left(c 0.1, \mathrm{CH}_{3} \mathrm{OH}\right)$; UV $\left(\mathrm{CH}_{3} \mathrm{OH}\right) \lambda_{\max }(\log \varepsilon) 276(1.67), 239(2.37) \mathrm{nm} ; \mathrm{ECD}\left(\mathrm{CH}_{3} \mathrm{OH}\right) \lambda_{\max }(\Delta \varepsilon) 282(-0.22), 259$ (-0.24), 212 (+0.83); IR (neat) $v_{\max } 3327,2979,2922,1603,1504,1449,1318,1218,1054,1033$, $1015 \mathrm{~cm}^{-1} ;{ }^{1} \mathrm{H}$ and ${ }^{13} \mathrm{C}$ NMR data, see Table 1; HRESIMS $m / z$ 577.2233 [M - H] ${ }^{-}$(calcd. for $\mathrm{C}_{36} \mathrm{H}_{33} \mathrm{O}_{7}$, 577.2226). 
Table 1. NMR spectroscopic data $\left(800 \mathrm{MHz}\right.$, methanol- $\left.\mathrm{d}_{4}\right)$ for obovatolins A (1) and B (2).

\begin{tabular}{|c|c|c|c|c|c|c|}
\hline \multirow[b]{2}{*}{ Position } & \multicolumn{3}{|c|}{ Obovatolin A (1) } & \multicolumn{3}{|c|}{ Obovatolin B (2) } \\
\hline & $\delta_{C}$ & Type & $\delta_{\mathrm{H}}(J$ in $\mathrm{Hz})$ & $\delta_{C}$ & Type & $\delta_{\mathrm{H}}(J$ in $\mathrm{Hz})$ \\
\hline 2 & 82.1 & $\mathrm{CH}$ & $4.80 \mathrm{~d}(6.3)$ & 82.1 & $\mathrm{CH}$ & $4.79 \mathrm{~d}(5.6)$ \\
\hline 3 & 68.4 & $\mathrm{CH}$ & $4.10 \mathrm{~m}$ & 68.4 & $\mathrm{CH}$ & $4.07 \mathrm{~m}$ \\
\hline $4 a$ & 30.3 & $\mathrm{CH}_{2}$ & $2.83 \mathrm{dd}(16.4,5.0)$ & 32.8 & $\mathrm{CH}_{2}$ & $2.91 \mathrm{dd}(16.4,4.7)$ \\
\hline $4 b$ & & & $2.66 \mathrm{dd}(16.4,6.8)$ & & & $2.77 \mathrm{dd}(16.4,6.3)$ \\
\hline 5 & 130.2 & $\mathrm{C}$ & & 130.3 & $\mathrm{CH}$ & $6.88 \mathrm{~d}(2.2)$ \\
\hline 6 & 115.1 & $\mathrm{CH}$ & $6.34 \mathrm{~s}$ & 133.1 & $\mathrm{C}$ & \\
\hline 7 & 143.0 & $\mathrm{C}$ & & 131.1 & $\mathrm{CH}$ & $6.84 \mathrm{~d}(2.2)$ \\
\hline 8 & 136.9 & $\mathrm{C}$ & & 127.7 & $\mathrm{C}$ & \\
\hline 9 & 144.6 & $\mathrm{C}$ & & 150.6 & $\mathrm{C}$ & \\
\hline 10 & 116.8 & $\mathrm{C}$ & & 121.5 & $\mathrm{C}$ & \\
\hline $1^{\prime}$ & 131.3 & $\mathrm{C}$ & & 131.6 & $\mathrm{C}$ & \\
\hline $2^{\prime}$ & 111.2 & $\mathrm{CH}$ & $6.46 \mathrm{~d}(1.9)$ & 110.7 & $\mathrm{CH}$ & $6.36 \mathrm{~d}(2.2)$ \\
\hline $3^{\prime}$ & 145.6 & C & & 145.3 & $\mathrm{C}$ & \\
\hline $4^{\prime}$ & 138.0 & $\mathrm{C}$ & & 137.6 & $\mathrm{C}$ & \\
\hline $5^{\prime}$ & 148.1 & $\mathrm{C}$ & & 147.9 & $\mathrm{C}$ & \\
\hline $6^{\prime}$ & 110.4 & $\mathrm{CH}$ & $6.71 \mathrm{~d}(1.9)$ & 110.0 & $\mathrm{CH}$ & $6.61 \mathrm{~d}(2.2)$ \\
\hline $1^{\prime \prime}$ & 37.4 & $\mathrm{CH}_{2}$ & $3.19 \mathrm{~d}(6.2)$ & 40.49 & $\mathrm{CH}_{2}$ & 3.33 overlap \\
\hline $2^{\prime \prime}$ & 137.8 & $\mathrm{CH}$ & $5.84 \mathrm{~m}$ & 139.3 & $\mathrm{CH}$ & 5.96 overlap \\
\hline $3^{\prime \prime}$ & 116.0 & $\mathrm{CH}_{2}$ & $4.92 \mathrm{~m}$ & 115.8 & $\mathrm{CH}_{2}$ & $5.05 \mathrm{~m}$ \\
\hline $1^{\prime \prime \prime}$ & 134.9 & C & & 132.1 & $\mathrm{C}$ & \\
\hline $2^{\prime \prime \prime}$ & 130.5 & $\mathrm{CH}$ & $7.06 \mathrm{~d}(8.6)$ & 132.5 & $\mathrm{CH}$ & $6.70 \mathrm{~d}(2.0)$ \\
\hline $3^{\prime \prime \prime}$ & 117.7 & $\mathrm{CH}$ & $6.78 \mathrm{~d}(8.6)$ & 127.0 & $\mathrm{C}$ & \\
\hline $4^{\prime \prime \prime}$ & 158.1 & $\mathrm{C}$ & & 153.7 & $\mathrm{C}$ & \\
\hline $5^{\prime \prime \prime}$ & 117.7 & $\mathrm{CH}$ & $6.78 \mathrm{~d}(8.6)$ & 116.8 & $\mathrm{CH}$ & $6.72 \mathrm{~d}(8.2)$ \\
\hline $6^{\prime \prime \prime}$ & 130.5 & $\mathrm{CH}$ & $7.06 \mathrm{~d}(8.6)$ & 129.5 & $\mathrm{CH}$ & $6.91 \mathrm{dd}(8.2,2.0)$ \\
\hline $7^{\prime \prime \prime}$ & 40.41 & $\mathrm{CH}_{2}$ & 3.32 overlap & 40.4 & $\mathrm{CH}_{2}$ & $3.20 \mathrm{~d}(6.8)$ \\
\hline $8^{\prime \prime \prime}$ & 139.1 & $\mathrm{CH}$ & 5.94 overlap & 139.6 & $\mathrm{CH}$ & $5.89 \mathrm{~m}$ \\
\hline $9^{\prime \prime \prime}$ & 115.8 & $\mathrm{CH}_{2}$ & $4.98 \mathrm{~m}$ & 115.4 & $\mathrm{CH}_{2}$ & $4.98 \mathrm{~m}$ \\
\hline $1^{\prime \prime \prime \prime}$ & 135.5 & C & & 135.3 & C & \\
\hline $2^{\prime \prime \prime \prime}$ & 130.6 & $\mathrm{CH}$ & $7.08 \mathrm{~d}(8.6)$ & 130.6 & $\mathrm{CH}$ & $7.04 \mathrm{~d}(8.5)$ \\
\hline $3^{\prime \prime \prime \prime}$ & 118.4 & $\mathrm{CH}$ & $6.86 \mathrm{~d}(8.6)$ & 118.3 & $\mathrm{CH}$ & $6.76 \mathrm{~d}(8.5)$ \\
\hline $4^{\prime \prime \prime \prime \prime}$ & 157.5 & C & & 157.4 & $\mathrm{C}$ & \\
\hline $5^{\prime \prime \prime \prime}$ & 118.4 & $\mathrm{CH}$ & $6.86 \mathrm{~d}(8.6)$ & 118.3 & $\mathrm{CH}$ & $6.76 \mathrm{~d}(8.5)$ \\
\hline $6^{\prime \prime \prime \prime}$ & 130.6 & $\mathrm{CH}$ & $7.08 \mathrm{~d}(8.6)$ & 130.6 & $\mathrm{CH}$ & $7.04 \mathrm{~d}(8.5)$ \\
\hline $7^{\prime \prime \prime \prime \prime}$ & 40.39 & $\mathrm{CH}_{2}$ & 3.32 overlap & 40.46 & $\mathrm{CH}_{2}$ & 3.33 overlap \\
\hline $8^{\prime \prime \prime \prime}$ & 139.2 & $\mathrm{CH}$ & 5.93 overlap & 139.1 & $\mathrm{CH}$ & 5.95 overlap \\
\hline $9^{\prime \prime \prime \prime \prime}$ & 115.7 & $\mathrm{CH}_{2}$ & $5.03 \mathrm{~m}$ & 115.7 & $\mathrm{CH}_{2}$ & $5.04 \mathrm{~m}$ \\
\hline
\end{tabular}

Obovatolin B (2): pale yellow, amorphous solid; $[\alpha]_{D}^{20} 169.4$ (c 0.1, MeOH); UV $\left(\mathrm{CH}_{3} \mathrm{OH}\right) \lambda_{\max }(\log \varepsilon) 284$ (1.56), $233(2.34) \mathrm{nm} ; \mathrm{ECD}\left(\mathrm{CH}_{3} \mathrm{OH}\right) \lambda_{\max }(\Delta \varepsilon) 293(-0.19)$, $273(-0.20), 250(-0.22), 221(+0.77), 210(+0.85)$; IR (neat) $v_{\max } 3363,2930,1639,1603$, 1504, 1434, 1218, 1033, 1017, $917 \mathrm{~cm}^{-1} ;{ }^{1} \mathrm{H}$ and ${ }^{13} \mathrm{C}$ NMR data, see Table 1 ; HRESIMS $\mathrm{m} / \mathrm{z}$ $561.2257[\mathrm{M}-\mathrm{H}]^{-}$(calcd. for $\mathrm{C}_{36} \mathrm{H}_{33} \mathrm{O}_{6}, 561.2277$ ).

\subsection{Cell Culture, Drugs and Chemicals}

The HepG2 human hepatocellular liver cell line was purchased from the Korea Research Institute of Bioscience and Biotechnology (Daejeon, Korea). These cells were grown in Eagle's Minimum Essential Medium (EMEM) containing 10\% fetal bovine serum with $100 \mathrm{U} / \mathrm{mL}$ penicillin/streptomycin sulfate. Cells were incubated in a humidified $5 \% \mathrm{CO}_{2}$ atmosphere at $37^{\circ} \mathrm{C}$. EMEM, penicillin, and streptomycin were purchased from Hyclone (Logan, UT, USA). Bovine serum albumin was purchased from Sigma-Aldrich (St. Louis, MO, USA). 


\subsection{Quantitative Real-Time RT-PCR}

A Trizol RNA extraction kit was used for isolation of total cellular RNA according to the manufacturer's instructions. Briefly, for cDNA synthesis from RNA, total RNA (1 $\mu \mathrm{g})$ was treated with 200 units reverse transcriptase and $500 \mathrm{ng}$ oligo-dT primers in $50 \mathrm{mM}$ Tris- $\mathrm{HCl}$ (pH 8.3), $75 \mathrm{mM} \mathrm{KCl}, 3 \mathrm{mM} \mathrm{MgCl} 2,10 \mathrm{mM}$ dithiothreitol, and $1 \mathrm{mM}$ dNTPs at $42{ }^{\circ} \mathrm{C}$ for $1 \mathrm{~h}$. The reaction was quenched with incubating the solution at $70{ }^{\circ} \mathrm{C}$ for $15 \mathrm{~min}$. PCR reactions were conducted using $1 \mu \mathrm{L}$ cDNA and $9 \mu \mathrm{L}$ master mix containing TB Green ${ }^{\mathrm{TM}}$ Premix Ex Taq ${ }^{\mathrm{TM}}$ II (Takara, Kyoto, Japan), 5 pmol of forward primer, and 5 pmol reverse primer, in a CFX384 Real-Time PCR Detection System (Bio-Rad, Hercules, CA, USA). The specificity of the amplification was confirmed by a melting curve analysis. CFX Manager Software (Bio-Rad) was used for data collecting and recording as a function of the threshold cycle $\left(\mathrm{C}_{\mathrm{T}}\right)$. The relative quantity of the controlled gene was normalized compared to the relative quantity of GAPDH $(\Delta \Delta C T)$. The equation $2^{-(\Delta \Delta C T)}$ was used for calculating the mRNA abundance. Gene-specific primers were custom-synthesized by Bioneer (Daejeon, Korea). The specific primer sets are shown in Table S1.

\subsection{Immunoblot Analysis}

Western blot was carried out according to standard procedures [29]. Images were acquired using a ChemiDoc Imaging system (ChemiDoc ${ }^{\mathrm{TM}}$ XRS system with Image $\mathrm{Lab}^{\mathrm{TM}}$ software 3.0; Bio-Rad, Hercules, CA, USA).

\subsection{Statistical Analysis}

For multiple comparisons, one-way analysis of variance (ANOVA) was performed followed by Dunnett's $t$-test. Fold changes and statistic calculations were performed using BIO-RAD CFX Maestro 1.1 software. Data from experiments are presented as means \pm standard error of the mean (SEM).

\subsection{Selection of Candidate Genes and Construction of Protein-Protein Interaction Network}

The protein-protein interaction networks of PCSK9 were constructed using online database resource Search Tool for the Retrieval of Interacting Genes (STRING) (http:/ / string-db.org/, accessed on 19 March 2021) [30] and visualized using Cytoscape software. In this study, STRING was used for interactions among proteins encoded by candidate genes, which was significantly changed by 1 . A $p$-value $<0.05$ was set as the cut-off criterion.

\subsection{ADMET (Absorption, Distribution, Metabolism, Excretion and Toxicity) Analysis}

The active compound $\mathbf{1}$ was subjected to ADMET property calculation using the chemoinformatic tool, pkCSM [31]. The SMILES of the compound was submitted to pkCSM web server (http:/ / biosig.unimelb.edu.au/pkcsm/prediction_single/adme_1615762956.8 2, accessed on 19 March 2021) and its pharmacokinetic properties were predicted [32].

\section{Results and Discussion}

The methanol extract of M. obovata barks was partitioned using $n$-hexane, chloroform, ethyl acetate, $n$-butanol, and water. Through preliminary bioassay, the $n$-hexane fraction was found to inhibit PCSK9 mRNA expression (Figure S1). The $n$-hexane fraction was further fractionated by a silica gel column chromatography to yield 11 subfractions, and then these subfractions were analyzed by UHPLC-Q-ToF-MS/MS (negative-ion mode).

\subsection{Dereplication Using GNPS Molecular Networking and Network Annotation Propagation (NAP)}

To reveal chemical diversity of $n$-hexane fraction, the MS/MS data of subfractions were analyzed by the GNPS MS/MS molecular networking. In the network, nodes are indicative of a consensus MS spectra and edges represent spectral similarity between any two given nodes [10]. The resulting MS/MS molecular networking depicted constituents of the $n$ hexane fraction as 208 nodes, consisting of 23 molecular families (MFs) and 97 singletons 
(single nodes without any correlation) [3] (Figure 1). Most of molecular families were estimated to have lignan moieties based on in silico annotation via Network Annotation Propagation (NAP) module in GNPS (Figure S2). The molecular families A-C represented lignans made from allylphenyl groups. MF A was a big cluster composed of nodes with $\mathrm{m} / \mathrm{z}$ $300-1100$, which was further subdivided into sesquiterpene-lignans or tri-lignans classes. MF B represented neolignans consisting of two allylphenyl monomers with $\mathrm{m} / \mathrm{z} 240-330$ molecular weight ranges. A small cluster MF $\mathrm{C}$ was annotated to be dilignans made from allylphenyl moieties by analysis of MS/MS data and NAP module. Compounds in MF C were subjected to be isolated for discovering new dilignans and affirming robustness of the dereplication tool used.

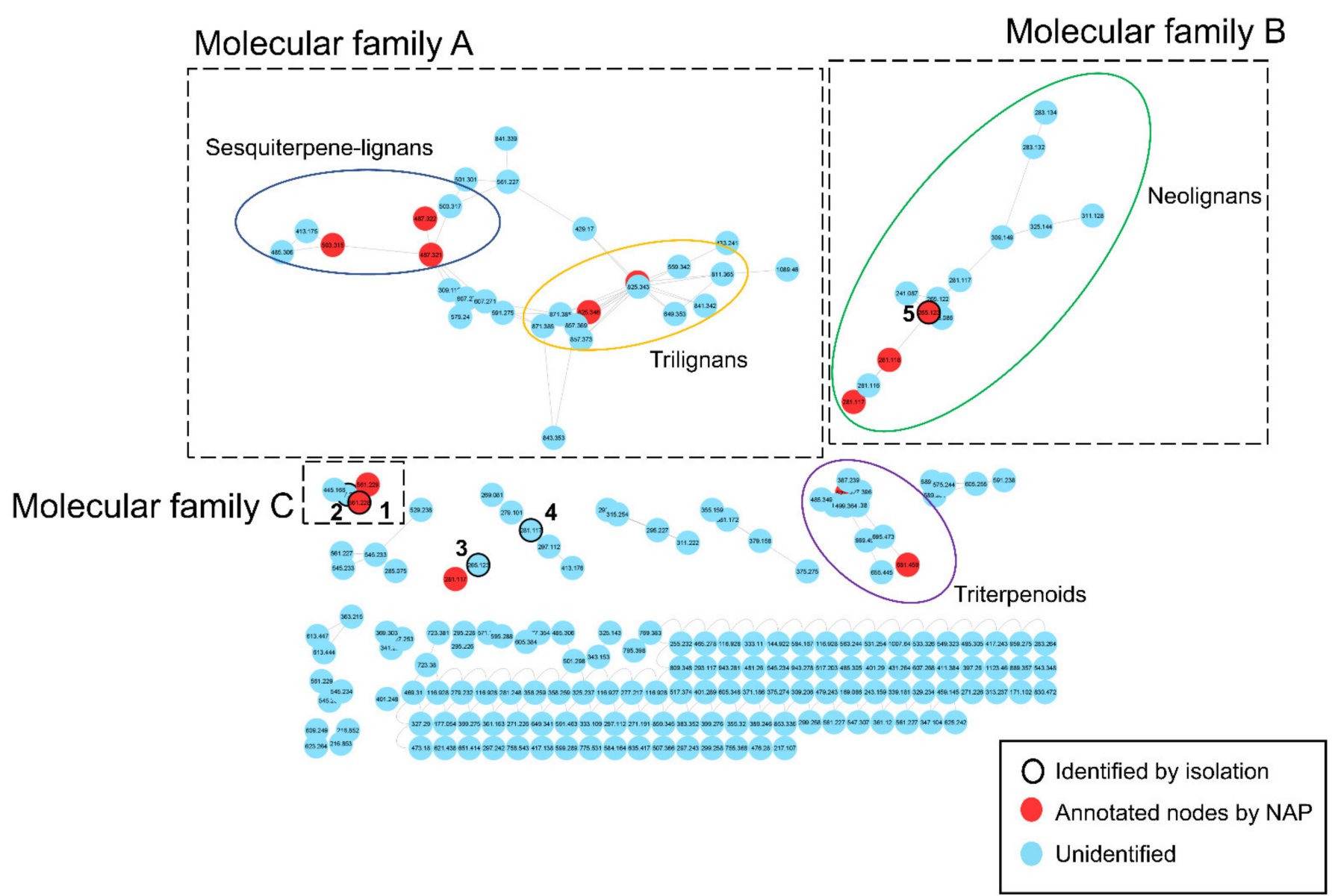

Figure 1. The MS/MS molecular network from the LC-MS/MS data of the $n$-hexane fraction of M. obovata barks.

\subsection{Isolation and Structural Characterization}

Two new dilignans with a 2-phenyl-3-chromanol motif (1 and 2, Figure 2) made from allylphenyl groups were isolated from stem barks of $M$. obovata by targeted isolation using the LC-MS/MS-based molecular networking. In addition, the known neolignans composed of two allylphenol, magnolol (3) [33], obovatol (4) [33], and honokiol (5) [33], along with known (-)-syringaresinol (6) [33], (+)-pinoresinol (7) [34], and (-)-demethoxypinoresinol (8) [35] were purified and identified by comparison of their spectroscopic data and literatures. 


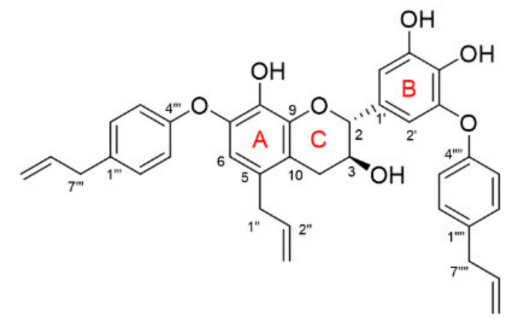

1

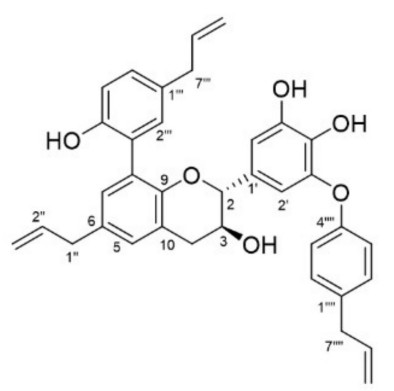

2

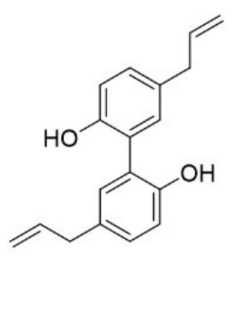

3

Figure 2. New compounds $(\mathbf{1}, \mathbf{2})$ and active magnolol (3).

Obovatolin A (1) was obtained as a pale yellow, amorphous solid. Its molecular formula was deduced to be $\mathrm{C}_{36} \mathrm{H}_{34} \mathrm{O}_{7}$ by the observed deprotonated molecule at $\mathrm{m} / \mathrm{z}$ 577.2233 [M - H] $]^{-}$(calcd. for $\mathrm{C}_{36} \mathrm{H}_{33} \mathrm{O}_{7}, 577.2226$ ). Two 1,4-disubstituted aromatic rings at $\delta_{\mathrm{H}} 7.08\left(2 \mathrm{H}, \mathrm{d}, J=8.6 \mathrm{~Hz}, \mathrm{H}-2^{\prime \prime \prime \prime}, 6^{\prime \prime \prime \prime}\right), 7.06\left(2 \mathrm{H}, \mathrm{d}, J=8.6 \mathrm{~Hz}, \mathrm{H}-2^{\prime \prime \prime}, 6^{\prime \prime \prime}\right), 6.86(2 \mathrm{H}, \mathrm{d}$, $\left.J=8.6 \mathrm{~Hz}, \mathrm{H}-3^{\prime \prime \prime \prime}, 5^{\prime \prime \prime \prime}\right)$, and $6.78\left(2 \mathrm{H}, \mathrm{d}, J=8.6 \mathrm{~Hz}, \mathrm{H}-3^{\prime \prime \prime}, 5^{\prime \prime \prime}\right)$, one pair of meta-coupled aromatic protons due to a 1,3,4,5-tetrasubstituted benzene ring $(B)$ at $\delta_{\mathrm{H}} 6.71(1 \mathrm{H}, \mathrm{d}$, $\left.J=1.9 \mathrm{~Hz}, \mathrm{H}-6^{\prime}\right)$, and $6.46\left(1 \mathrm{H}, \mathrm{d}, J=1.9 \mathrm{~Hz}, \mathrm{H}-2^{\prime}\right)$, and one singlet aromatic proton at $\delta_{\mathrm{H}}$ $6.34(1 \mathrm{H}, \mathrm{s}, \mathrm{H}-6)$ assignable to a 1,2,3,4,5-pentasubstituted benzene ring (A), were observed in the ${ }^{1} \mathrm{H}$ NMR spectrum (Table 1), along with the COSY cross peaks between $\mathrm{H}-2^{\prime}$ and $\mathrm{H}-6^{\prime}$, between $\mathrm{H}-2^{\prime \prime \prime}$ and $\mathrm{H}-3^{\prime \prime \prime}$, and between $\mathrm{H}-2^{\prime \prime \prime \prime}$ and $\mathrm{H}-3^{\prime \prime \prime \prime}$ (Figure 3). Additionally, the presence of three allyl groups was confirmed by ${ }^{1} \mathrm{H}-{ }^{1} \mathrm{H}$ COSY correlations of $\delta_{\mathrm{H}} 5.84(1 \mathrm{H}$, $\left.\mathrm{m}, \mathrm{H}-2^{\prime \prime}\right)$ with $\delta_{\mathrm{H}} 3.19\left(2 \mathrm{H}, \mathrm{d}, J=6.2 \mathrm{~Hz}, \mathrm{H}-1^{\prime \prime}\right)$ and $4.92\left(2 \mathrm{H}, \mathrm{m}, \mathrm{H}-3^{\prime \prime}\right)$, and of $\delta_{\mathrm{H}} 6.00-5.88$ $\left(2 \mathrm{H}\right.$, overlap, $\mathrm{H}-8^{\prime \prime \prime}$ and $\left.8^{\prime \prime \prime \prime}\right)$ with $\delta_{\mathrm{H}} 3.32\left(4 \mathrm{H}\right.$, overlap, $\mathrm{H}-7^{\prime \prime \prime}$ and $\left.7^{\prime \prime \prime \prime}\right)$ and 5.07-4.95 $(4 \mathrm{H}$, overlap, $\mathrm{H}-9^{\prime \prime \prime}$ and $\left.9^{\prime \prime \prime \prime}\right)$. The remaining ${ }^{1} \mathrm{H}$ NMR signals were attributed to the spin system of $-\mathrm{CH}(\mathrm{O})-\mathrm{CH}(\mathrm{O})-\mathrm{CH}_{2}$ - in 1, which was confirmed by the COSY correlations of $\delta_{\mathrm{H}} 4.10$ $(1 \mathrm{H}, \mathrm{m}, \mathrm{H}-3)$ with $\delta_{\mathrm{H}} 4.80(1 \mathrm{H}, \mathrm{d}, J=6.3 \mathrm{~Hz}, \mathrm{H}-2), 2.83(1 \mathrm{H}, \mathrm{dd}, J=16.4,5.0 \mathrm{~Hz}, \mathrm{H}-4 \mathrm{a})$, and $2.66(1 \mathrm{H}, \mathrm{dd}, J=16.4,6.8 \mathrm{~Hz}, \mathrm{H}-4 \mathrm{~b})$. Based on these data, it was suggested that the structure 1 is a dilignan composed of four phenylpropanoids. The ${ }^{13} \mathrm{C}$ NMR and HSQC spectra showed quaternary aromatic carbon signals that include eight oxygenated carbons at $\delta_{\mathrm{C}} 158.1\left(\mathrm{C}-4^{\prime \prime \prime}\right), 157.5\left(\mathrm{C}-4^{\prime \prime \prime \prime}\right), 148.1\left(\mathrm{C}-5^{\prime}\right), 145.6\left(\mathrm{C}-3^{\prime}\right), 144.6(\mathrm{C}-9), 143.0(\mathrm{C}-7), 138.0$ $\left(\mathrm{C}-4^{\prime}\right), 136.9(\mathrm{C}-8)$, and five non-protonated carbons at $\delta_{\mathrm{C}} 135.5\left(\mathrm{C}-1^{\prime \prime \prime \prime}\right), 134.9\left(\mathrm{C}-1^{\prime \prime \prime}\right), 131.3$ $\left(\mathrm{C}-1^{\prime}\right), 130.2(\mathrm{C}-5)$ and $116.8(\mathrm{C}-10)$.

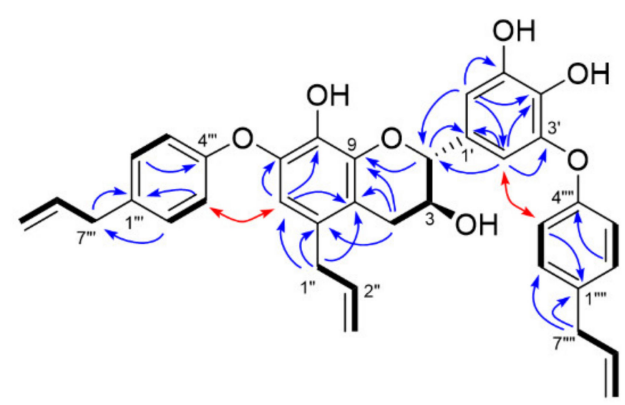

1

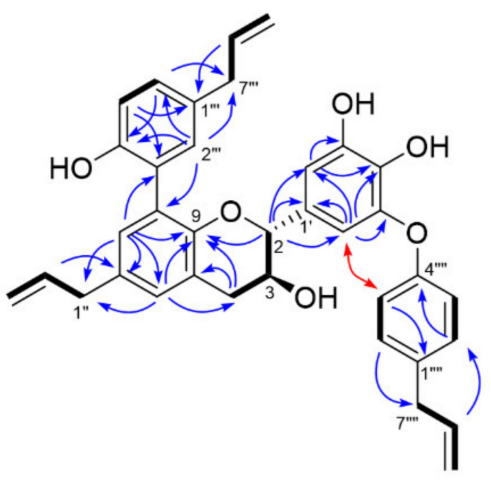

2

Figure 3. ${ }^{1} \mathrm{H}-{ }^{1} \mathrm{H}$ COSY (thick black line), key HMBC (blue arrow), and ROESY (red arrow) correlations of compounds 1 and 2.

The HMBC correlations from $\mathrm{H}-2^{\prime \prime \prime \prime}$ to $\mathrm{C}-7^{\prime \prime \prime \prime}$, from $\mathrm{H}-6$ to $\mathrm{C}-1^{\prime \prime}$, and from $\mathrm{H}-2^{\prime \prime \prime}$ to C-7"l' enabled to locate three allyl groups to each benzene ring. Further HMBC correlations from $\mathrm{H}-3^{\prime \prime \prime}$ and $\mathrm{H}-\mathrm{7}^{\prime \prime \prime}$ to $\mathrm{C}-1^{\prime \prime \prime}$, from $\mathrm{H}-2^{\prime \prime \prime}$ to $\mathrm{C}-4^{\prime \prime \prime}$, from $\mathrm{H}-3^{\prime \prime \prime \prime}$ and $\mathrm{H}-7^{\prime \prime \prime \prime}$ to $\mathrm{C}-\mathrm{1}^{\prime \prime \prime \prime}$, 
and from $\mathrm{H}-2^{\prime \prime \prime \prime}$ to $\mathrm{C}-4^{\prime \prime \prime \prime}$ were indicative of the presence of two 4-allylphenol groups. Additionally, the HMBC spectrum showed the correlations of H-1" with C-5, C-6 and C-10, and of H-6 with C-7, C-8 and C-10, suggesting the remaining allyl group was attached to the A ring. The assignment of the 1,3,4,5-tetrasubstituted benzene ring (B) was deduced by the HMBC cross peaks of $\mathrm{H}-2^{\prime}$ with $\mathrm{C}-1^{\prime}, \mathrm{C}-3^{\prime}$ and $\mathrm{C}-4^{\prime}$, and of $\mathrm{H}-6^{\prime}$ with $\mathrm{C}-4^{\prime}$ and $\mathrm{C}-5^{\prime}$. The chromanol moiety $\mathrm{C}$-ring $\left[-\mathrm{CH}(\mathrm{O})-\mathrm{CH}(\mathrm{O})-\mathrm{CH}_{2}-\right]$ in $\mathbf{1}$ was supported by the $\mathrm{HMBC}$ correlations from $\mathrm{H}-2$ to $\mathrm{C}-9$ and $\mathrm{C}-1^{\prime}$, from $\mathrm{H}-2^{\prime}$ and $\mathrm{H}-6^{\prime}$ to $\mathrm{C}-2$, and from $\mathrm{H}-4$ to $\mathrm{C}-5$, C-9 and C-10. Two 4-allylphenol groups were connected via ether linkages at C-7 and C- $3^{\prime}$, respectively, confirmed by the ROESY correlations of $\mathrm{H}-6$ with $\mathrm{H}-3^{\prime \prime \prime}$, and of $\mathrm{H}-2^{\prime}$ with $\mathrm{H}-3^{\prime \prime \prime \prime}$. The trans configuration between $\mathrm{H}-2$ and $\mathrm{H}-3$ was verified by the coupling constant $\left(J_{2,3}=6.3 \mathrm{~Hz}\right)$ [36]. The absolute configuration was determined to be $2 R$ and $3 S$ on the basis of the ECD spectrum, which showed negative Cotton effect at $275 \mathrm{~nm}$ [37]. Therefore, the structure of $\mathbf{1}$ was deduced as (2R,3S)-5-allyl-7-(4-allylphenoxy)-2-(3-(4allylphenoxy)-4,5-dihydroxyphenyl)chromane-3,8-diol, a dilignan derived from two units of obovatol.

Obovatolin B (2) was isolated as pale yellow, amorphous solid. The molecular formula, $\mathrm{C}_{36} \mathrm{H}_{34} \mathrm{O}_{6}$, was determined based on HRESIMS $\left(\mathrm{m} / \mathrm{z} 561.2257[\mathrm{M}-\mathrm{H}]^{-}\right.$; calcd. for $\left.\mathrm{C}_{36} \mathrm{H}_{33} \mathrm{O}_{6}, 561.2277\right)$ and NMR data analysis. Two 1,3,4,5-tetrasubstituted benzene rings at $\delta_{\mathrm{H}} 6.36\left(1 \mathrm{H}, \mathrm{d}, J=2.2 \mathrm{~Hz}, \mathrm{H}-2^{\prime}\right), 6.61\left(1 \mathrm{H}, \mathrm{d}, J=2.2 \mathrm{~Hz}, \mathrm{H}-6^{\prime}\right), 6.84(1 \mathrm{H}, \mathrm{d}, J=2.2 \mathrm{~Hz}$, $\mathrm{H}-7)$, and $6.88(1 \mathrm{H}, \mathrm{d}, J=2.2 \mathrm{~Hz}, \mathrm{H}-5)$, one 1,4-disubstituted aromatic ring at $\delta_{\mathrm{H}} 6.76(2 \mathrm{H}$, $\left.\mathrm{d}, J=8.5 \mathrm{~Hz}, \mathrm{H}-3^{\prime \prime \prime \prime}, 5^{\prime \prime \prime \prime}\right)$, and $7.04\left(2 \mathrm{H}, \mathrm{d}, J=8.5 \mathrm{~Hz}, \mathrm{H}-2^{\prime \prime \prime \prime}, 6^{\prime \prime \prime \prime}\right)$, one 1,3,4-trisubstituted benzene ring at $\delta_{\mathrm{H}} 6.70\left(1 \mathrm{H}, \mathrm{d}, J=2.0 \mathrm{~Hz}, \mathrm{H}-2^{\prime \prime \prime}\right), 6.72\left(1 \mathrm{H}, \mathrm{d}, J=8.2 \mathrm{~Hz}, \mathrm{H}-5^{\prime \prime \prime}\right)$, and 6.91 $\left(1 \mathrm{H}, \mathrm{dd}, J=8.2,2.0 \mathrm{~Hz}, \mathrm{H}-6^{\prime \prime \prime}\right)$ were observed in the ${ }^{1} \mathrm{H}$ NMR spectroscopic data along with the COSY correlations of $\mathrm{H}-5$ with $\mathrm{H}-7, \mathrm{H}-2^{\prime}$ with $\mathrm{H}-6^{\prime}, \mathrm{H}-5^{\prime \prime \prime}$ with $\mathrm{H}-6^{\prime \prime \prime}$, and $\mathrm{H}-2^{\prime \prime \prime \prime}$ with $\mathrm{H}-3^{\prime \prime \prime \prime}$ (Figure 3). Additionally, three allyl groups were deduced by ${ }^{1} \mathrm{H}_{-}{ }^{1} \mathrm{H}$ COSY correlations of $\delta_{\mathrm{H}} 5.89\left(1 \mathrm{H}, \mathrm{m}, \mathrm{H}-8^{\prime \prime \prime}\right)$ with $\delta_{\mathrm{H}} 3.20\left(2 \mathrm{H}, \mathrm{d}, J=6.8 \mathrm{~Hz}, \mathrm{H}-7^{\prime \prime \prime}\right)$ and $4.98(2 \mathrm{H}$, $\left.\mathrm{m}, \mathrm{H}-9^{\prime \prime \prime}\right)$, and of $\delta_{\mathrm{H}} 5.96-5.95\left(2 \mathrm{H}\right.$, overlap, $\mathrm{H}-2^{\prime \prime}$ and $\left.8^{\prime \prime \prime \prime}\right)$ with $\delta_{\mathrm{H}} 3.33(4 \mathrm{H}$, overlap, H-1" and $\left.7^{\prime \prime \prime \prime}\right)$ and 5.05-5.04 $\left(4 \mathrm{H}\right.$, overlap, $\mathrm{H}-3^{\prime \prime}$ and $\left.9^{\prime \prime \prime \prime}\right)$. Sequential COSY correlations of H-2 [ $\left.\delta_{\mathrm{H}} 4.79(1 \mathrm{H}, \mathrm{d}, J=5.6 \mathrm{~Hz}, \mathrm{H}-2)\right] / \mathrm{H}-3\left[\delta_{\mathrm{H}} 4.07(1 \mathrm{H}, \mathrm{m}, \mathrm{H}-3)\right] / \mathrm{H}-4$ [ $(2.91(1 \mathrm{H}, \mathrm{dd}, J=16.4$, $4.7 \mathrm{~Hz}, \mathrm{H}-4 \mathrm{a})$ and $2.77(1 \mathrm{H}, \mathrm{dd}, J=16.4,6.3 \mathrm{~Hz}, \mathrm{H}-4 \mathrm{~b})]$ indicated the presence of the spin system of $-\mathrm{CH}(\mathrm{O})-\mathrm{CH}(\mathrm{O})-\mathrm{CH}_{2}$ - in 2.

The ${ }^{13} \mathrm{C}$ NMR and HSQC spectra displayed quaternary aromatic carbon signals that include six oxygenated carbons at $\delta_{C} 157.4\left(\mathrm{C}-4^{\prime \prime \prime \prime}\right), 153.7\left(\mathrm{C}-4^{\prime \prime \prime}\right), 150.6(\mathrm{C}-9), 147.9\left(\mathrm{C}-5^{\prime}\right)$, $145.3\left(\mathrm{C}-3^{\prime}\right)$ and $137.6\left(\mathrm{C}-4^{\prime}\right)$, and seven non-oxygenated carbons at $\delta_{\mathrm{C}} 135.3\left(\mathrm{C}-1^{\prime \prime \prime \prime}\right), 133.1$ (C-6), $132.1\left(\mathrm{C}-1^{\prime \prime \prime}\right), 131.6\left(\mathrm{C}-1^{\prime}\right), 127.7$ (C-8), $127.0\left(\mathrm{C}-3^{\prime \prime \prime}\right)$ and 121.5 (C-10). A 5-substituted magnolol moiety was confirmed by the HMBC spectrum which showed the cross spots of $\mathrm{H}-5$ with C-9 and C-1", of H-7 with C-6, C-9, C-1" and C- $3^{\prime \prime \prime}$, of H-2"' with C-8, C-4" $4^{\prime \prime \prime}$ and $C-7^{\prime \prime \prime}$, of $\mathrm{H}-5^{\prime \prime \prime}$ with $\mathrm{C}-1^{\prime \prime \prime}$ and $\mathrm{C}-3^{\prime \prime \prime}$, and of $\mathrm{H}-6^{\prime \prime \prime}$ with $\mathrm{C}-4^{\prime \prime \prime}$ and $\mathrm{C}-7^{\prime \prime \prime}$. The HMBC correlations of $\mathrm{H}-2^{\prime \prime \prime \prime}$ with $\mathrm{C}-4^{\prime \prime \prime \prime}$ and $\mathrm{C}-7^{\prime \prime \prime \prime}$, and of $\mathrm{H}-3^{\prime \prime \prime \prime}$ with $\mathrm{C}-1^{\prime \prime \prime \prime}$ confirmed presence of a remaining 4-allylphenol group, which was attached to $\mathrm{B}$ ring via ether linkage at $\mathrm{C}-3^{\prime}$, supported by the ROESY correlations between $\mathrm{H}-3^{\prime \prime \prime \prime}$ and $\mathrm{H}-2^{\prime}$.

The chromanol moiety C-ring $\left[-\mathrm{CH}(\mathrm{O})-\mathrm{CH}(\mathrm{O})-\mathrm{CH}_{2}-\right]$ in 2 was supported by the $\mathrm{HMBC}$ correlations from $\mathrm{H}-2$ to $\mathrm{C}-9, \mathrm{C}-1^{\prime}, \mathrm{C}-2^{\prime}$ and $\mathrm{C}-6^{\prime}$, from $\mathrm{H}-4$ to $\mathrm{C}-9$ and $\mathrm{C}-10$, and from $\mathrm{H}-5$ to $\mathrm{C}-4$. The relative and absolute configurations of 2 were determined to be identical to those of 1 from its coupling constant between $\mathrm{H}-2$ and $\mathrm{H}-3\left(\mathrm{~J}_{2,3}=5.6 \mathrm{~Hz}\right)$ and its ECD spectrum. These spectroscopic data supported the structure of $\mathbf{2}$ as (2R,3S)-6-allyl-8-(5-allyl2-hydroxyphenyl)-2-(3-(4-allylphenoxy)-4,5-dihydroxyphenyl)chromane-3-ol, a dilignan composed of one obovatol and one magnolol.

\subsection{Biological Assay for PCSK9 mRNA Inhibitory Effect}

All the isolates 1-8 were tested in PCSK9 mRNA expression using HepG2 cell (Figure 4). Out of them, 1, 2, and magnolol (3) were found to inhibit PCSK9 mRNA expression with $\mathrm{IC}_{50}$ values of 12.0, 45.4 and $22.9 \mu \mathrm{M}$ (berberine $\mathrm{IC}_{50} 13.3 \mu \mathrm{M}$ ), respectively (Figure 5), while other compounds deemed inactive. These data suggested that new compounds 1, 2, and a 
major constituent, magnolol (3) from the stem barks of $M$. obovata could potentially increase cellular LDL-cholesterol uptakes in the plasma through inhibition of PCSK9 expression. Of active compounds, compound 1, the most potent inhibitor of PCSK9 mRNA expression, was further tested for additional lipid metabolism-related gene expressions analysis.

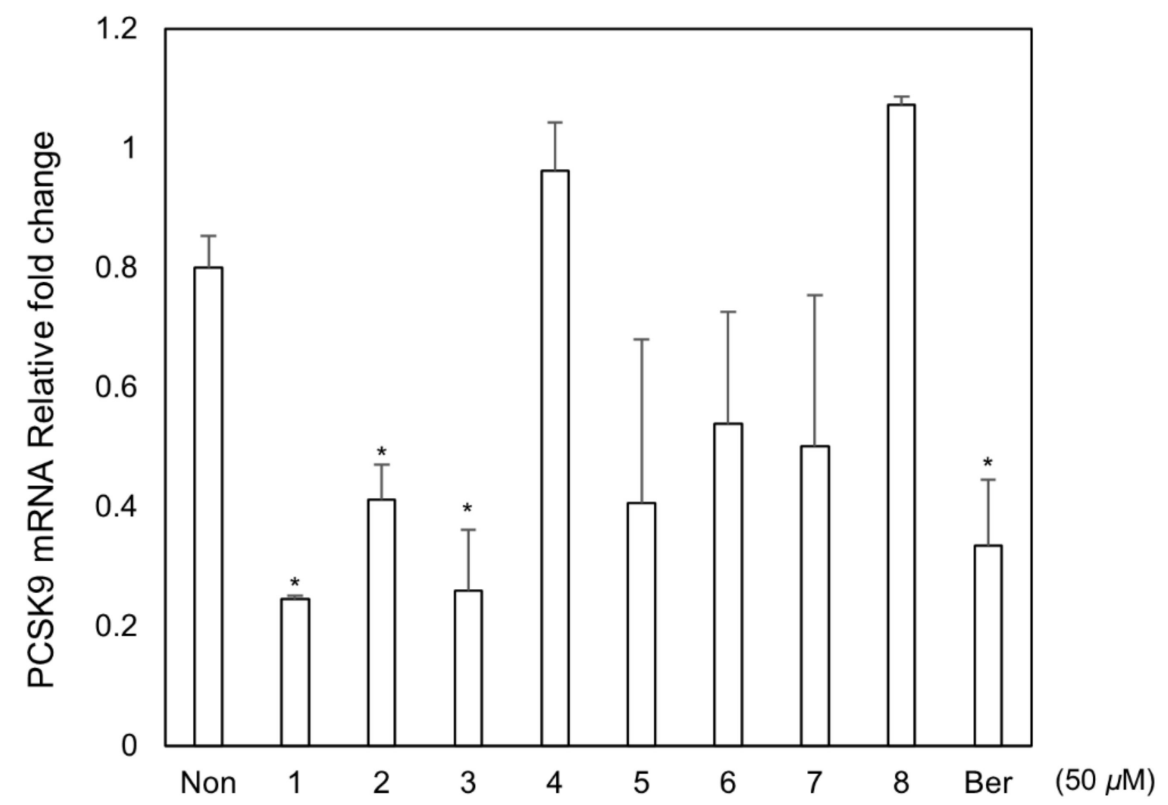

Figure 4. Effect of isolates from M. obovata on PCSK9 in the HepG2 human hepatocellular liver carcinoma cell line. Expression of PCSK9 mRNA was assayed by qRT-PCR in cells treated with each compound $(50 \mu \mathrm{M})$, or positive control, berberine (Ber, $50 \mu \mathrm{M})$ for $24 \mathrm{~h}$. ${ }^{*} p<0.05$.
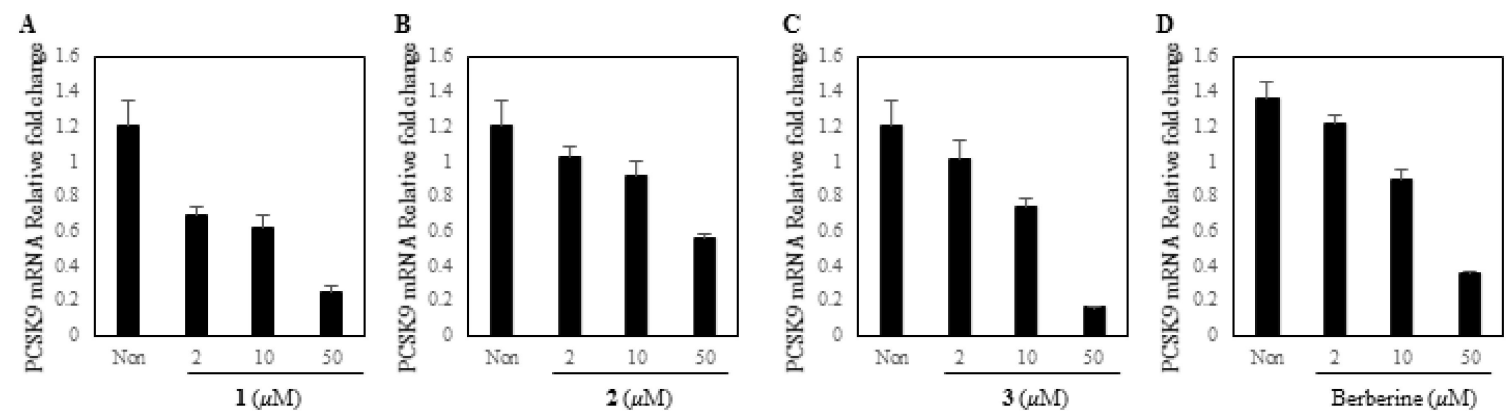

Figure 5. Effect of active compounds on PCSK9 in the HepG2 human hepatocellular liver carcinoma cell line. PCSK9 mRNA inhibitory effects of $\mathbf{1}$ (A), 2 (B), and magnolol (3) (C) were comparable with positive control, berberine (D).

\subsection{Construction of Protein-Protein Interaction Network of Candidate Genes}

Further Western blotting analysis showed that $\mathbf{1}$ decreased PCSK9 protein levels in HepG2 cells as well as increased LDLR expression as comparable to berberine (positive control) (Figure 6).

Small set of lipid metabolism-related genes (42 genes) were selected from the STRING database, and their expressions caused by $\mathbf{1}$ were tested (Table S1). As a result, the genes significantly sensitive to the treatment of $\mathbf{1}$ were observed and the regulated genes were chosen based on $p$-value to generate the interaction network. Further, the STRING database was used to analyze the interaction of those genes. The protein-protein interaction network (Figure 7) indicated that PCSK9 downregulation by 1 might be associated with upregulation of nuclear receptor subfamily 1 group $\mathrm{H}$ member 3 (NR1H3), also known as LXR $\alpha$ (Liver $\mathrm{X}$ receptor $\alpha$ ), and peroxisome proliferator activated receptor $\alpha$ (PPARA) genes expression. Additionally, downstream target genes of transcriptional factors such as Acyl- 
CoA synthetase long-chain family 6 (ACSL6), carnitine palmitoyl transferase 1A (CPT1A), and apolipoprotein B (APOB) were upregulated or downregulated. The ACSL6, CPT1A, and APOB genes control fatty acid metabolism, triglyceride metabolism, and catabolism of lipoprotein particles, respectively [38-40].

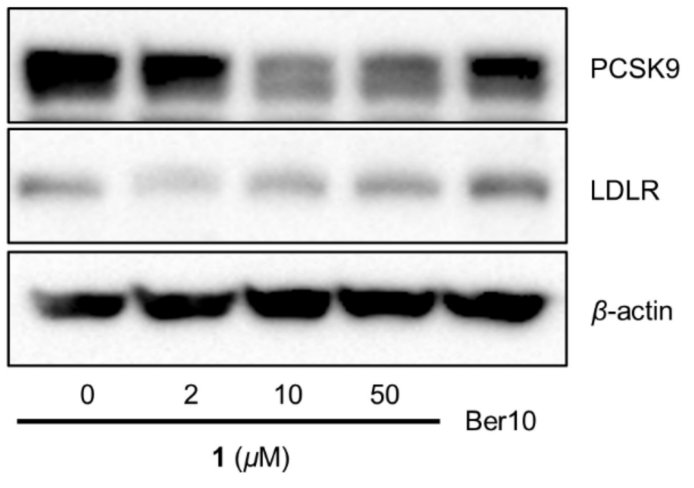

Figure 6. Effects of 1 on PCSK9 and LDLR expressions in the HepG2 human hepatocellular liver carcinoma cell line. Expressions of PCSK9 and LDLR were assayed by Western blot in cells treated with 1 and berberine (Ber, $10 \mu \mathrm{M}$ ) for $24 \mathrm{~h}$.

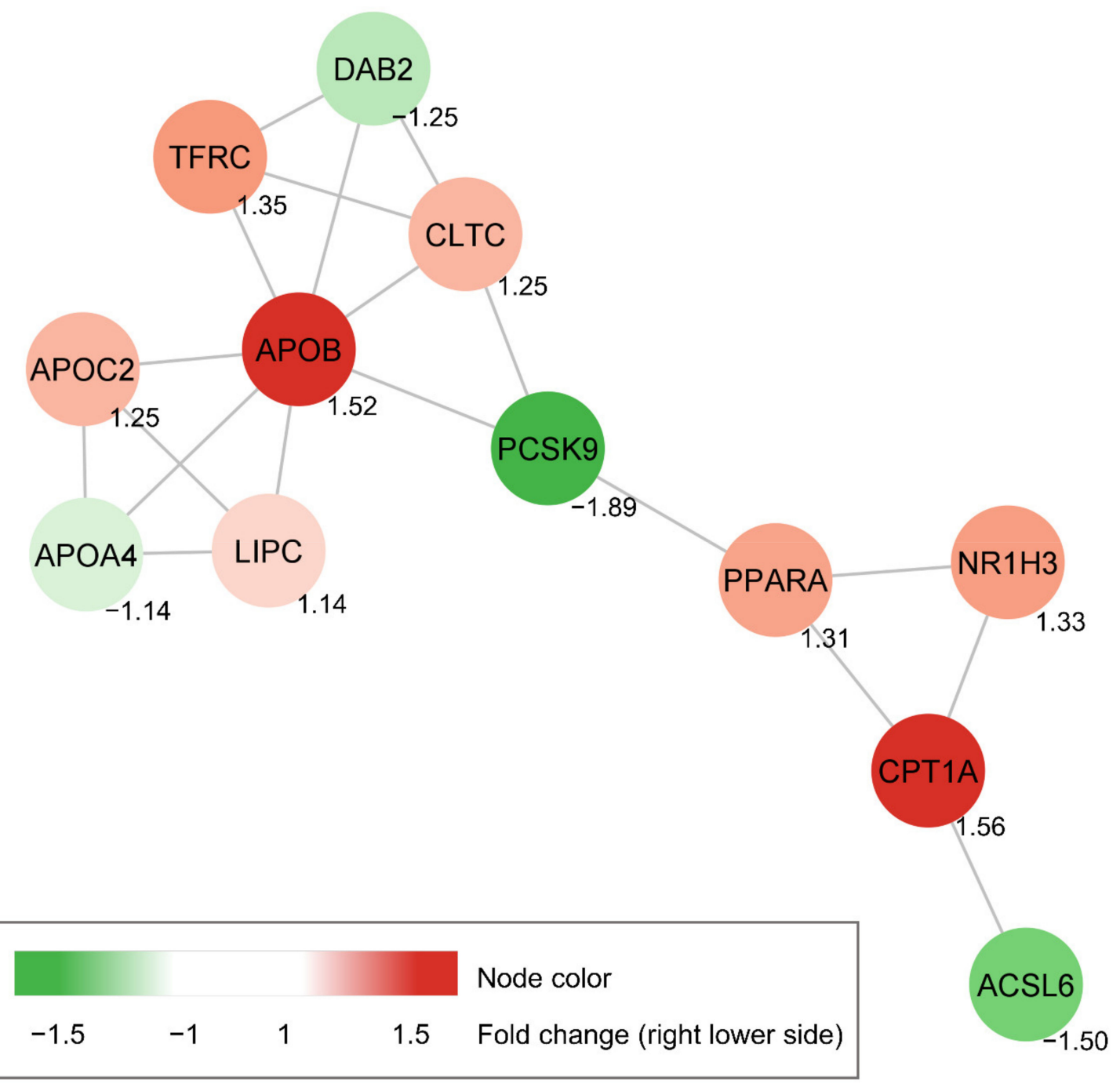

Figure 7. The protein-protein interaction network of the PCSK9-related genes significantly changed by 1. PCSK9-related gene profiling of HepG2 cells treated with 1 for $24 \mathrm{~h}$. 


\title{
3.5. ADMET Studies
}

The pharmacokinetic properties of $\mathbf{1}$ were calculated by the pkCSM and the data are shown in Figure S19. According to the predicted pharmacokinetic properties, $\mathbf{1}$ is poorly soluble in water but has great human intestinal absorption ( $87 \%$ ability). It has the steady state volume of distribution (VDss) value of -1.251 , which indicates this compound may be distributed more in blood plasma than in tissues [41]. This compound $\mathbf{1}$ is also considered to be cytochrome P 450 enzymes (CYP) inhibitors such as CYP2C9 inhibitor, and CYP3A4 inhibitor. Cytochrome P 450 enzymes (CYP) metabolize many statins used for cholesterol-lowering drugs. CYP3A4 metabolizes atorvastatin and lovastatin and CYP2C9 metabolizes rosuvastatin and fluvastatin [42,43]. Thus, compound $\mathbf{1}$ has potential drug interaction with specific statins.

\section{Conclusions}

Implementation of MN strategy with the in silico annotation tools in natural product discovery is expected to expedite the dereplication of several secondary metabolites. Two new dilignans with a 2-phenyl-3-chromanol motif, obovatolins A (1) and B (2), were identified using these tools, resulting in an expansion of the chemical diversity with lignan skeleton in M. obovata. This study also suggested that new compounds $(\mathbf{1}, \mathbf{2})$, and a major magnolol (3) have potential of decreasing LDL-C in the plasma through inhibition of PCSK9 expression. In addition, the results herein showed correlations between lipid metabolism-related gene expressions under presence of $\mathbf{1}$, which may help understand the lipid metabolism caused by 1 .

Supplementary Materials: The following are available online at https:/ /www.mdpi.com/2218-273 X/11/3/463/s1, Detailed in silico annotations, IR, NMR, HRMS, UV, and ECD spectra of $\mathbf{1}$ and 2 , as well as preliminary results of fractions for PCSK9 inhibitory activity and the qPCR results for some selected genes treated by 1 .

Author Contributions: Conceptualization, J.A. and Y.-W.C.; experimental, J.A., H.-S.C., P.P. and Y.-M.K.; writing, J.A. and Y.-W.C.; review, Y.H.C. and J.K. All authors have read and agreed to the published version of the manuscript.

Funding: This research was funded by the National Research Foundation of Korea (NRF) in the Korean government (MSIT) (grant number NRF-2019R1A2C2009053).

Institutional Review Board Statement: Not applicable.

Informed Consent Statement: Not applicable.

Data Availability Statement: Publicly available datasets were analyzed in this study. This data can be found here: [https://gnps.ucsd.edu/ProteoSAFe/status.jsp?task=3a3d98903cbc4cc5bbb214fa0 c7d1ce4], [https://proteomics2.ucsd.edu/ProteoSAFe/status.jsp?task=680053703c2b49f7ab43888 2c6badab1], [http://string-db.org/], and [http://biosig.unimelb.edu.au/pkcsm/prediction_single/ adme_1615762956.82] (accessed on 19 March 2021).

Conflicts of Interest: The authors declare no conflict of interest.

\author{
Abbreviations \\ LC-MS/MS Liquid chromatography tandem mass spectrometry \\ MN Molecular networking \\ LDL-C Low-density lipoprotein cholesterol \\ PCSK9 Proprotein convertase subtilisin/kexin type 9 \\ LDLR Low-density lipoprotein receptor \\ GNPS Global Natural Products Social Molecular Networking \\ NAP Network Annotation Propagation \\ HRESIMS High resolution-electrospray ionization-mass spectroscopy \\ SEM Standard error of the mean
}


STRING Search Tool for the Retrieval of Interacting Genes

ADMET Absorption, Distribution, Metabolism, Excretion and Toxicity

MFs Molecular families

VDss Steady state Volume of Distribution

CYP Cytochrome P 450 enzyme

\section{References}

1. Newman, D.J.; Cragg, G.M. Natural products as sources of new drugs over the nearly four decades from $01 / 1981$ to $09 / 2019$. J. Nat. Prod. 2020, 83, 770-803. [CrossRef] [PubMed]

2. Gaudencio, S.P.; Pereira, F. Dereplication: Racing to speed up the natural products discovery process. Nat. Prod. Rep. 2015, 32, 779. [CrossRef]

3. Kang, K.B.; Woo, S.; Ernst, M.; van der Hooft, J.J.J.; Nothias, L.-F.; da Silva, R.R.; Dorrestein, P.C.; Sung, S.H.; Lee, M. Assessing specialized metabolite diversity of Alnus species by a digitized LC-MS/MS data analysis workflow. Phytochemistry 2020, 173, 112292. [CrossRef] [PubMed]

4. Woo, S.; Kang, K.B.; Kim, J.; Sung, S.H. Molecular networking reveals the chemical diversity of selaginellin derivatives, natural phosphodiesterase-4 inhibitors from Selaginella tamariscina. J. Nat. Prod. 2019, 82, 1820-1830. [CrossRef] [PubMed]

5. Marner, M.; Patras, M.A.; Kurz, M.; Zubeil, F.; Förster, F.; Schuler, S.; Bauer, A.; Hammann, P.; Vilcinskas, A.; Schäberle, T.F.; et al. Molecular networking-guided discovery and characterization of stechlisins, a group of cyclic lipopeptides from a Pseudomonas sp. J. Nat. Prod. 2020, 83, 2607-2617. [CrossRef] [PubMed]

6. Olivon, F.; Allard, P.-M.; Koval, A.; Righi, D.; Genta-Jouve, G.; Neyts, J.; Apel, C.; Pannecouque, C.; Nothias, L.-F.; Cachet, X.; et al. Bioactive natural products prioritization using massive multi-informational molecular networks. ACS Chem. Biol. 2017, 12, 2644-2651. [CrossRef]

7. Yang, J.Y.; Sanchez, L.M.; Rath, C.M.; Liu, X.; Boudreau, P.D.; Bruns, N.; Glukhov, E.; Wodtke, A.; de Felicio, R.; Fenner, A.; et al. Molecular networking as a dereplication strategy. J. Nat. Prod. 2013, 76, 1686-1699. [CrossRef]

8. Nothias, L.-F.; Nothias-Esposito, M.; da Silva, R.; Wang, M.; Protsyuk, I.; Zhang, Z.; Sarvepalli, A.; Leyssen, P.; Touboul, D.; Costa, J.; et al. Bioactivity-based molecular networking for the discovery of drug leads in natural product bioassay-guided fractionation. J. Nat. Prod. 2018, 81, 758-767. [CrossRef] [PubMed]

9. Nothias-Esposito, M.; Nothias, L.F.; da Silva, R.R.; Retailleau, P.; Zhang, Z.; Leyssen, P.; Roussi, F.; Touboul, D.; Paolini, J.; Dorrestein, P.C.; et al. Investigation of premyrsinane and myrsinane esters in Euphorbia cupanii and Euphobia pithyusa with MS2LDA and combinatorial molecular network annotation propagation. J. Nat. Prod. 2019, 82, 1459-1470. [CrossRef] [PubMed]

10. Da Silva, R.R.; Wang, M.; Nothias, L.-F.; van der Hooft, J.J.J.; Caraballo-Rodríguez, A.M.; Fox, E.; Balunas, M.J.; Klassen, J.L.; Lopes, N.P.; Dorrestein, P.C. Propagating annotations of molecular networks using in silico fragmentation. PLoS ONE 2018, 14, e1006089. [CrossRef]

11. Yi, Z.; Zhu, Z.-J. Overview of tandem mass spectral and metabolite databases for metabolite identification in metabolomics. In Computational Methods and Data Analysis for Metabolomics; Li, S., Ed.; Springer: New York, NY, USA, 2014; pp. 139-148. ISBN 9781071602386.

12. Alla, V.M.; Agrawal, V.; DeNazareth, A.; Mohiuddin, S.; Ravilla, S.; Rendell, M. A reappraisal of the risks and benefits of treating to target with cholesterol lowering drugs. Drugs 2013, 73, 1025-1054. [CrossRef] [PubMed]

13. Rosenson, R.S.; Hegele, R.A.; Fazio, S.; Cannon, C.P. The evolving future of PCSK9 inhibitors. J. Am. Coll. Cardiol. 2018, 72, 314-329. [CrossRef] [PubMed]

14. Kotowski, I.K.; Pertsemlidis, A.; Luke, A.; Cooper, R.S.; Vega, G.L.; Cohen, J.C.; Hobbs, H.H. A spectrum of PCSK9 alleles contributes to plasma levels of low-density lipoprotein cholesterol. Am. J. Hum. Genet. 2006, 78, 410-422. [CrossRef] [PubMed]

15. Ahn, J.; Kim, Y.; Chae, H.; Choi, Y.H.; Ahn, H.; Yoo, H.; Kang, M.; Kim, J.; Chin, Y.-W. Prenylated flavonoids from the roots and rhizomes of Sophora tonkinensis and their effects on the expression of inflammatory mediators and proprotein convertase subtilisin/kexin type 9. J. Nat. Prod. 2019, 82, 309-317. [CrossRef] [PubMed]

16. Su, Z.; Hang, P.; Hu, J.; Zheng, Y.; Sun, H.; Guo, J.; Liu, K.; Du, Z. Aloe-emodin exerts cholesterol-lowering effects by inhibiting proprotein convertase subtilisin/kexin type 9 in hyperlipidemic rats. Acta Pharmacol. Sin. 2020, 41, 1085-1092. [CrossRef]

17. Li, H.; Li, J.; Zhang, X.; Li, J.; Xi, C.; Wang, W.; Lu, Y.; Xuan, L. 23,24-Dihydrocucurbitacin B promotes lipid clearance by dual transcriptional regulation of LDLR and PCSK9. Acta Pharmacol. Sin. 2020, 41, 327-335. [CrossRef]

18. Dong, B.; Li, H.; Singh, A.B.; Cao, A.; Liu, J. Inhibition of PCSK9 transcription by berberine involves down-regulation of hepatic HNF1 $\alpha$ protein expression through the ubiquitin-proteasome degradation pathway. J. Biol. Chem. 2015, 290, 4047-4058. [CrossRef]

19. Pel, P.; Chae, H.-S.; Nhoek, P.; Kim, Y.-M.; Khiev, P.; Kim, G.J.; Nam, J.-W.; Choi, H.; Choi, Y.H.; Chin, Y.-W. A stilbene dimer and flavonoids from the aerial parts of Chromolaena odorata with proprotein convertase subtilisin/kexin type 9 expression inhibitory activity. Bioorg. Chem. 2020, 99, 103869. [CrossRef]

20. Baek, Y.-S.; Seo, K.-H.; Lee, D.-Y.; Kwon, O.-K.; Baek, N.-I. A new neolignan, isoobovatol, from the fruits of Magnolia obovata. Chem. Nat. Compd. 2016, 52, 986-988. [CrossRef]

21. Seo, K.-H.; Lee, D.-Y.; Lee, Y.-G.; Baek, N.-I. Dineolignans of 3-O-4' diphenyl ether-type from fruits of Magnolia obovata. Phytochemistry 2017, 136, 133-140. [CrossRef] 
22. Matsuda, H.; Kageura, T.; Oda, M.; Morikawa, T.; Sakamoto, Y.; Yoshikawa, M. Effects of constituents from the bark of Magnolia obovata on nitric oxide production in lipopolysaccharide-activated macrophages. Chem. Pharm. Bull. 2001, 49, 716-720. [CrossRef] [PubMed]

23. Patočka, J.; Jakl, J.; Strunecká, A. Expectations of biologically active compounds of the genus Magnolia in biomedicine. J. Appl. Biomed. 2006, 4, 171-178. [CrossRef]

24. Sarrica, A.; Kirika, N.; Romeo, M.; Salmona, M.; Diomede, L. Safety and Toxicology of Magnolol and Honokiol. Planta Med. 2018, 84, 1151-1164. [CrossRef] [PubMed]

25. Lee, W.J.; Moon, J.S.; Kim, S.I.; Bahn, Y.-S.; Lee, H.; Kang, T.H.; Shin, H.M.; Kim, S.U. A phenylpropanoid glycoside as a calcineurin inhibitor isolated from Magnolia obovata Thunb. J. Microbiol. Biotechnol. 2015, 25, 1429-1432. [CrossRef] [PubMed]

26. Seo, K.-H.; Lee, D.-Y.; Jung, J.-W.; Lee, D.-S.; Kim, Y.-C.; Lee, Y.-H.; Baek, N.-I. Neolignans from the Fruits of Magnolia obovata inhibit NO production and have neuroprotective effects. Helv. Chim. Acta 2016, 99, 411-415. [CrossRef]

27. Wang, M.; Carver, J.J.; Phelan, V.V.; Sanchez, L.M.; Garg, N.; Peng, Y.; Nguyen, D.D.; Watrous, J.; Kapono, C.A.; Luzzatto-Knaan, T.; et al. Sharing and community curation of mass spectrometry data with Global Natural Products Social Molecular Networking. Nat. Biotechnol. 2016, 34, 828-837. [CrossRef]

28. Kang, K.B.; Park, E.J.; da Silva, R.R.; Kim, H.W.; Dorrestein, P.C.; Sung, S.H. Targeted isolation of neuroprotective dicoumaroyl neolignans and lignans from Sageretia theezans using in silico molecular network annotation propagation-based dereplication. $J$. Nat. Prod. 2018, 81, 1819-1828. [CrossRef]

29. Chae, H.-S.; You, B.H.; Kim, D.-Y.; Lee, H.; Ko, H.W.; Ko, H.-J.; Choi, Y.H.; Choi, S.S.; Chin, Y.-W. Sauchinone controls hepatic cholesterol homeostasis by the negative regulation of PCSK9 transcriptional network. Sci. Rep. 2018, 8, 6737. [CrossRef]

30. Szklarczyk, D.; Gable, A.L.; Lyon, D.; Junge, A.; Wyder, S.; Huerta-Cepas, J.; Simonovic, M.; Doncheva, N.T.; Morris, J.H.; Bork, P.; et al. STRING v11: Protein-protein association networks with increased coverage, supporting functional discovery in genome-wide experimental datasets. Nucleic Acids Res. 2019, 47, D607-D613. [CrossRef]

31. Pires, D.E.V.; Blundell, T.L.; Ascher, D.B. pkCSM: Predicting small-molecule pharmacokinetic and toxicity properties using graph-based signatures. J. Med. Chem. 2015, 58, 4066-4072. [CrossRef]

32. Lagorce, D.; Douguet, D.; Miteva, M.A.; Villoutreix, B.O. Computational analysis of calculated physicochemical and ADMET properties of protein-protein interaction inhibitors. Sci. Rep. 2017, 7, 46277. [CrossRef]

33. Lee, S.-K.; Kim, H.-N.; Kang, Y.-R.; Lee, C.W.; Kim, H.-M.; Han, D.C.; Shin, J.; Bae, K.; Kwon, B.-M. Obovatol inhibits colorectal cancer growth by inhibiting tumor cell proliferation and inducing apoptosis. Bioorg. Med. Chem. 2008, 16, 8397-8402. [CrossRef] [PubMed]

34. Zhou, D.; Wei, H.; Jiang, Z.; Li, X.; Jiao, K.; Jia, X.; Hou, Y.; Li, N. Natural potential neuroinflammatory inhibitors from Alhagi sparsifolia Shap. Bioorg. Med. Chem. Lett. 2017, 27, 973-978. [CrossRef] [PubMed]

35. Zhou, L.; Han, F.-Y.; Lu, L.-W.; Yao, G.-D.; Zhang, Y.-Y.; Wang, X.-B.; Lin, B.; Huang, X.-X.; Song, S.-J. Isolation of enantiomeric furolactones and furofurans from Rubus idaeus L. with neuroprotective activities. Phytochemistry 2019, 164, 122-129. [CrossRef]

36. Shen, C.-C.; Chang, Y.-S.; Ho, L.-K. Nuclear magnetic resonance studies of 5,7-dihydroxyflavonoids. Phytochemistry 1993, 34, 843-845. [CrossRef]

37. Rinaldo, D.; Batista, J.M., Jr.; Rodrigues, J.; Benfatti, A.C.; Rodrigues, C.M.; Dos Santos, L.C.; Furlan, M.; Vilegas, W. Determination of catechin diastereomers from the leaves of Byrsonima species using chiral HPLC-PAD-CD. Chirality 2010, 22, 726-733. [CrossRef] [PubMed]

38. Sebastiano, M.R.; Konstantinidou, G. Targeting long chain acyl-Coa synthetases for cancer therapy. Int. J. Mol. Sci. 2019, 20, 3624. [CrossRef] [PubMed]

39. Bonnefont, J.-P.; Djouadi, F.; Prip-Buus, C.; Gobin, S.; Munnich, A.; Bastin, J. Carnitine palmitoyltransferases 1 and 2: Biochemical, molecular and medical aspects. Mol. Asp. Med. 2004, 25, 495-520. [CrossRef]

40. Drouin-Chartier, J.-P.; Tremblay, A.J.; Hogue, J.-C.; Lemelin, V.; Lamarche, B.; Couture, P. Plasma PCSK9 correlates with apoB-48-containing triglyceride-rich lipoprotein production in men with insulin resistance. J. Lipid Res. 2018, 59, 1501-1509. [CrossRef]

41. Jeyaraman, P.; Samuel, M.; Johnson, A.; Raman, N. Synthesis, characterization, ADMET, in vitro and in vivo studies of mixed ligand metal complexes from a curcumin Schiff base and lawsone. Nucleosides Nucleotides Nucleic Acids 2020, 40, 242-263. [CrossRef]

42. Willrich, M.A.V.; Hirata, M.H.; Hirata, R.D.C. Statin regulation of CYP3A4 and CYP3A5 expression. Pharmacogenomics 2009, 10, 1017-1024. [CrossRef] [PubMed]

43. Ming, E.E.; Davidson, M.H.; Gandhi, S.K.; Marotti, M.; Miles, C.G.; Ke, X.; McKenney, J.M. Concomitant use of statins and CYP3A4 inhibitors in administrative claims and electronic medical records databases. J. Clin. Lipidol. 2008, 2, 453-463. [CrossRef] [PubMed] 